Correspondence Wung Yang Shieh winyang@ntu.edu.tw

\section{Aliagarivorans marinus gen. nov., sp. nov. and Aliagarivorans taiwanensis sp. nov., facultatively anaerobic marine bacteria capable of agar degradation}

\author{
Wen Dar Jean, ${ }^{1}$ Ssu-Po Huang, ${ }^{2}$ Tung Yen Liu, ${ }^{2}$ Jwo-Sheng Chen ${ }^{3}$ \\ and Wung Yang Shieh ${ }^{2}$ \\ ${ }^{1}$ Center for General Education, Leader University, No. 188, Sec. 5, An-Chung Rd, Tainan, \\ Taiwan, ROC \\ ${ }^{2}$ Institute of Oceanography, National Taiwan University, PO Box 23-13, Taipei, Taiwan, ROC \\ ${ }^{3}$ College of Health Care, China Medical University, No. 91, Shyue-Shyh Rd, Taichung, Taiwan, ROC
}

Two agarolytic strains of Gram-negative, heterotrophic, facultatively anaerobic, marine bacteria, designated $A A M 1^{\top}$ and $A A T 1^{\top}$, were isolated from seawater samples collected in the shallow coastal region of An-Ping Harbour, Tainan, Taiwan. Cells grown in broth cultures were straight rods that were motile by means of a single polar flagellum. The two isolates required $\mathrm{NaCl}$ for growth and grew optimally at about $25-30{ }^{\circ} \mathrm{C}$, in $2-4 \% \mathrm{NaCl}$ and at $\mathrm{pH}$. They grew aerobically and could achieve anaerobic growth by fermenting D-glucose or other sugars. The major isoprenoid quinone was Q-8 (79.8-92.0\%) and the major cellular fatty acids were summed feature $3\left(\mathrm{C}_{16: 1} \omega 7 \mathrm{c}\right.$ and/or iso- $\left.\mathrm{C}_{15: 0} 2-\mathrm{OH} ; 26.4-35.6 \%\right), \mathrm{C}_{18: 1} \omega 7 \mathrm{c}(27.1-31.4 \%)$ and $\mathrm{C}_{16: 0}$ $(14.8-16.3 \%)$ in the two strains. Strains $A A M 1^{\top}$ and $A A T 1^{\top}$ had DNA G $+C$ contents of 52.9 and $52.4 \mathrm{~mol} \%$, respectively. The two strains had a $16 \mathrm{~S}$ rRNA gene sequence similarity of $98.6 \%$ and shared 84.9-92.4\% sequence similarity with the type strains of Agarivorans albus (91.292.4\%), eight Alteromonas species (84.9-87.1\%), two Aestuariibacter species (86.0-87.0\%), Bowmanella denitrificans (86.1-86.7\%), eight Glaciecola species (85.0-87.9\%) and Salinimonas chungwhensis (85.9-86.1\%). Despite their high sequence similarity, strains $A A M 1^{\top}$ and $\mathrm{AAT}^{\top}{ }^{\top}$ had a DNA-DNA relatedness value of only $4.5 \%$. The data obtained from these polyphasic taxonomic studies revealed that the two agarolytic isolates could be classified as representatives of two novel species in a new genus, Aliagarivorans gen. nov., with Aliagarivorans marinus sp. nov. [type strain is $\mathrm{AAM} 1^{\top}\left(=\mathrm{BCRC} 17888^{\top}=\mathrm{JCM} 15522^{\top}\right)$ ] as the type species and Aliagarivorans taiwanensis sp. nov. [type strain is $\mathrm{AAT}^{\top}\left(=\mathrm{BCRC} 17889^{\top}=\mathrm{JCM} 15537^{\top}\right)$ ] as a second species.
Agar, a complex polysaccharide extracted from marine red algae, is widely used as a gelling agent for microbiological culture media. Hydrolysis of this refractory material, a property found only among members of the domain 'Bacteria', is indicated by the development of softening, depressions or, in some cases, complete liquefaction of the agar surrounding colonies of agarolytic bacteria. Marine agarolytic bacteria are ubiquitous in coastal and estuarine regions. They include species of various genera belonging to the phyla 'Bacteroidetes' (previously known as the Cytophaga-Flavobacterium-Bacteroides) (Yoon et al., 2007), 'Proteobacteria' (Jean et al., 2006a; Shieh et al., 2008)

The GenBank/EMBL/DDBJ accession numbers for the 16S rRNA gene sequences of strains $A A M 1^{\top}$ and $A A T 1^{\top}$ are FJ167390 and FJ167391, respectively. and 'Verrucomicrobia' (Scheuermayer et al., 2006; Shieh \& Jean, 1998).

Two strains of agarolytic bacteria, $\mathrm{AAM1}^{\mathrm{T}}$ and $\mathrm{AAT} 1^{\mathrm{T}}$, were isolated in our laboratory from seawater samples collected in the shallow coastal region of An-Ping Harbour, Tainan, Taiwan, during a survey of the diversity of marine agarolytic bacteria in Taiwan. Data from the present polyphasic study indicated that the two isolates could be classified as representatives of two different species in a new genus belonging to the class Gammaproteobacteria.

An-Ping Harbour is located in the south-west coast of Taiwan. Seawater samples were collected from the shallow coastal regions of this harbour in the morning at low tide. Each sample was decimally diluted to the order of $10^{-3}$ 
with sterile $\mathrm{NaCl}$-Tris buffer $(30 \mathrm{~g} \mathrm{NaCl}$ and $0.24 \mathrm{~g}$ Tris base in $1 \mathrm{l}$ deionized water, $\mathrm{pH} 8.0)$. Aliquots $(0.1 \mathrm{ml})$ of the 10 -fold dilutions $\left(10^{-1}\right.$ to $\left.10^{-3}\right)$ were spread onto polypeptone-yeast extract (PY) plate medium (Shieh et al., 2000) in triplicate. The plates were incubated at $25{ }^{\circ} \mathrm{C}$ in the dark for 7 days under aerobic conditions. Individual colonies that appeared to be agarolytic were picked off and purified by successive streaking on PY plates. Maintenance of the isolates in our laboratory was performed regularly at intervals of 3-4 months by inoculating early stationary phase cultures grown in PY broth into 7/10-strength seawater at a ratio of $1: 25(\mathrm{v} / \mathrm{v})$. Maintenance cultures were kept at $20{ }^{\circ} \mathrm{C}$ under aerobic conditions. Lyophilized cultures of both strains were also created.

Physiological and morphological characterization of $\mathrm{AAM}^{\mathrm{T}}$ and $\mathrm{AAT} 1^{\mathrm{T}}$, including growth and other phenotypic properties, was carried out according to previously described established procedures (Jean et al., 2006b), with modifications and additional tests as described below. Hydrolysis of chitin and cellulose was tested by growth of the strains on modified PY plate media containing either colloidal chitin or cellulose at $2 \mathrm{~g} \mathrm{l}^{-1}$ (Shieh et al., 2008). Haemolysis was tested as described by Chiu et al. (2007). Utilization of various compounds as sole carbon and energy sources for growth was tested in carbohydrate/ mineral (CM) media (Shieh et al., 2004) plus various carbon sources. Sugars and sugar alcohols were both provided at $5 \mathrm{~g} \mathrm{l}^{-1}$, whereas organic acids and amino acids were each provided at $2 \mathrm{~g} \mathrm{l}^{-1}$. All the test cultures were incubated aerobically at $30{ }^{\circ} \mathrm{C}$ in the dark for 7 days, unless stated otherwise.

Cells grown in PY broth and on PY plate medium at $30{ }^{\circ} \mathrm{C}$ for 7 days were used for analyses of cellular fatty acids, isoprenoid quinones and DNA $\mathrm{G}+\mathrm{C}$ content according to the methods described by Shieh et al. (2008). DNA-DNA hybridization between strains $\mathrm{AAM} 1^{\mathrm{T}}$ and $\mathrm{AATl}^{\mathrm{T}}$ was performed as described by Jean et al. (2009).

Cells grown in PY broth at $30{ }^{\circ} \mathrm{C}$ for 7 days were harvested by centrifugation. Extraction and purification of total genomic DNA from the cells and PCR amplification of $16 \mathrm{~S}$ rRNA genes were performed according to previously described methods (Jean et al., 2006b). Sequencing of the $16 \mathrm{~S}$ rRNA genes, alignment and comparison of the resulting sequences with reference sequences available in GenBank, calculation of distance matrices for the aligned sequences and reconstruction of phylogenetic trees based on the neighbour-joining, maximum-parsimony and maximum-likelihood methods were performed as described by Shieh et al. (2004) and Jean et al. (2006b). Stability of clusters was evaluated by bootstrap analysis of 1000 resamplings.

Nearly complete 16S rRNA gene sequences of strains $\mathrm{AAM}^{\mathrm{T}}$ and $\mathrm{AAT}^{\mathrm{T}}{ }^{\mathrm{T}}$ (1461 nt for each) were determined. Preliminary 16S rRNA gene sequence comparisons of the two sequences with those in GenBank revealed that the two novel isolates were members of the class
Gammaproteobacteria and were rather closely related to each other ( $98.6 \%$ sequence similarity, 21 differences out of $1461 \mathrm{nt}$ positions) than to strains of any recognized bacterial species ( $<93 \%$ sequence similarity). Strains $\mathrm{AAM}^{\mathrm{T}}$ and $\mathrm{AAT}^{\mathrm{T}}$ showed highest levels of sequence similarity to the type strains of Agarivorans albus (91.292.4\%; Kurahashi \& Yokota, 2004), eight Alteromonas species (84.9-87.1\%; Bowman \& McMeekin, 2005; Chiu et al., 2007; Ivanova et al., 2005; Martínez-Checa et al., 2005; Van Trappen et al., 2004a; Yoon et al., 2003, 2004), two Aestuariibacter species (86.0-87.0\%; Yi et al., 2004), Bowmanella denitrificans (86.1-86.7\%; Jean et al., 2006c), eight Glaciecola species (85.0-87.9\%; Baik et al., 2006; Bowman et al., 1998; Matsuyama et al., 2006; Romanenko et al., 2003; Yong et al., 2007; Van Trappen et al., 2004b; Zhang et al., 2006) and Salinimonas chungwhensis (85.9$86.1 \%$; Jeon et al., 2005). The distant relationship between the two novel isolates and these bacteria was also evident in the neighbour-joining tree, in which the two isolates formed a stable monophyletic clade (bootstrap value, $100 \%)$ located next to a sister clade comprising only Agarivorans albus strains (Fig. 1). The two isolates and Agarivorans albus (strain MKT $106^{\mathrm{T}}$ plus other reference strains), together with the type strains of various other species belonging to the Alteromonadaceae (eight Alteromonas species, eight Glaciecola species, two Aestuariibacter species, S. chungwhensis and B. denitrificans) formed a suprageneric monophyletic clade (Fig. 1). Similar results were obtained from the maximum-likelihood and maximum-parsimony algorithms (not shown). The low levels of $16 \mathrm{~S}$ rRNA gene sequence similarity to all recognized bacterial species $(<93 \%)$, together with the phylogenetic data from the three tree-making algorithms employed, showed that the two novel isolates could be assigned to a novel genus.

Strains $\mathrm{AAM}^{\mathrm{T}}$ and $\mathrm{AAT}^{\mathrm{T}}$, like Agarivorans albus and species of the genera Alteromonas, Glaciecola, Aestuariibacter, Salinimonas and Bowmanella, contained summed feature $3\left[\mathrm{C}_{16: 1} \omega 7 c\right.$ and/or iso- $\mathrm{C}_{15: 0} 2-\mathrm{OH}$ (the two fatty acids could not be differentiated in the MIDI system); $26.4-35.6 \%$ of the total fatty acids], $\mathrm{C}_{18: 1} \omega 7 c$ $(27.1-31.4 \%)$ and $\mathrm{C}_{16: 0}(14.8-16.3 \%)$ as the major fatty acids (Table 1). However, the fatty acid profiles of the two novel isolates could be distinguished from those of closely related species by differences in the levels of the fatty acids $\mathrm{C}_{18: 1} \omega 7 c(27.1-31.4 \%$ vs $0-19.4 \%)$, iso- $\mathrm{C}_{18: 0}(1.1-6.1 \%$ vs $0 \%$ to trace amount detected, with the exception of Alteromonas addita) and iso- $\mathrm{C}_{16: 0}(2.8-6.5 \%$ vs $0-1.5 \%$, with the exception of Agarivorans albus). Other quantitative differences in the fatty acids that might serve to differentiate the two novel isolates from the relevant species are listed in Table 1. Although strains $\mathrm{AAM}^{\mathrm{T}}$ and $\mathrm{AAT}^{\mathrm{T}}$ contained similar fatty acid profiles, their fatty acid profiles differed in the proportions of iso- $\mathrm{C}_{16: 0}(2.8 \%$ vs $6.5 \%)$, iso- $\mathrm{C}_{18: 0}(1.1 \%$ vs $6.1 \%)$ and summed feature $3(35.6 \%$ vs $26.4 \%)$. The two novel isolates contained Q- 8 as the predominant isoprenoid quinone $(92.0 \%$ for strain 


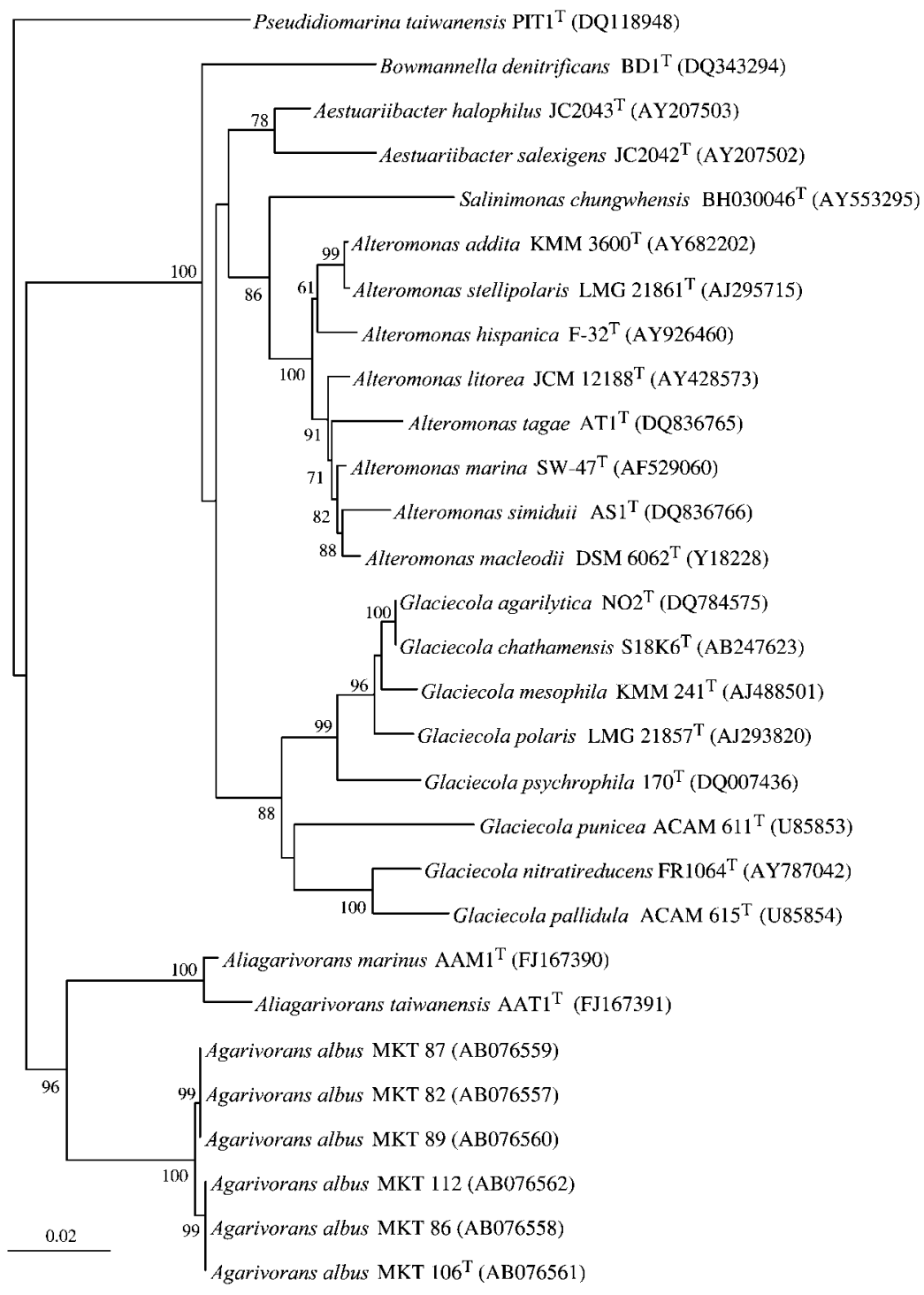

Fig. 1. Neighbour-joining tree showing the phylogenetic relationship between strains $A A M 1^{\top}$ and $A A T 1^{\top}$ and related bacteria in the class Gammaproteobacteria. GenBank accession numbers are given in parentheses. Bootstrap values (percentages of 1000 replicates) above $60 \%$ are shown at branch points. Bar, 2 nt substitution per 100 nt.

$\mathrm{AAM}^{\mathrm{T}}$ and $79.8 \%$ for strain $\mathrm{AAT} 1^{\mathrm{T}}$ ). The remaining isoprenoid quinones included RQ-10 (5.7\% for $\mathrm{AAM}^{\mathrm{T}}$ and $15.6 \%$ for $\mathrm{AAT}^{\mathrm{T}}$ ), Q-9 (1.8\% for $\mathrm{AAM}^{\mathrm{T}}$ and $2.0 \%$ for $\left.\mathrm{AAT}^{\mathrm{T}}\right)$ and MK-8 $\left(0.5 \%\right.$ for $\mathrm{AAM}^{\mathrm{T}}$ and $2.6 \%$ for $\left.\mathrm{AAT} 1^{\mathrm{T}}\right)$. They had DNA $\mathrm{G}+\mathrm{C}$ contents of 52.4$52.9 \mathrm{~mol} \%$, which were greater than those of Agarivorans albus (48.7-49.7 mol\%; Kurahashi \& Yokota, 2004), Alteromonas species (43.0-46.4 mol\%; Bowman \& McMeekin, 2005; Chiu et al., 2007; Ivanova et al., 2005; Martínez-Checa et al., 2005; Van Trappen et al., 2004a; Yoon et al., 2003, 2004), Glaciecola species (40.045.0 mol\%; Baik et al., 2006; Bowman et al., 1998; Matsuyama et al., 2006; Romanenko et al., 2003; Yong et al., 2007; Van Trappen et al., 2004b; Zhang et al., 2006), Aestuariibacter salexigens (48.0 mol\%; Yi et al., 2004), S. chungwhensis (48.0 mol\%; Jeon et al., 2005) and $B$. denitrificans (50.0 mol\%; Jean et al., 2006c). Aestuariibacter halophilus was the only species in the Alteromonadaceae that had a DNA $\mathrm{G}+\mathrm{C}$ content that was greater
(54.0 mol\%; Yi et al., 2004) than those of our isolates. DNA-DNA hybridization showed a DNA relatedness value of $4.5 \%$ between strains $\mathrm{AAM}^{\mathrm{T}}$ and $\mathrm{AAT}^{\mathrm{T}}$ when genomic DNA of the former isolate was used as a probe. The two isolates could be classified as two different genomic species according to this result. Taken together with phylogenetic results based on $16 \mathrm{~S}$ rRNA gene sequences and analyses of isoprenoid quinones and fatty acids, the two isolates can be classified as representing two distinct species in a novel genus.

Strains $\mathrm{AAM}^{\mathrm{T}}$ and $\mathrm{AAT} 1^{\mathrm{T}}$ were mesophilic, halophilic and Gram-negative. They produced circular, convex, offwhite, opaque and non-luminescent colonies surrounded by shallow depressions when grown on PY plate medium for 4-7 days. Clear yellow haloes formed around the colonies in contrast to the purple-brown background when the agar plates were flooded with iodine/potassium iodide solution (not shown). This indicated diffusion of agarase 
Table 1. Cellular fatty acid contents (\%) of strains $A A M 1^{\top}$ and $A A T 1^{\top}$ and members of the genera Agarivorans, Alteromonas, Glaciecola, Aestuariibacter, Salinimonas and Bowmanella

Taxa: 1, strain $\mathrm{AAM}^{\mathrm{T}}$ (data from this study); 2, strain $\mathrm{AAT}^{\mathrm{T}}$ (this study), 3, Agarivorans albus MKT 106 ${ }^{\mathrm{T}}$ (Kurahashi \& Yokota, 2004); 4, Alteromonas species [A. addita R10SW13 ${ }^{\mathrm{T}}$ (Ivanova et al., 2005), A. hispanica F-32 ${ }^{\mathrm{T}}$ (Martínez-Checa et al., 2005), A. litorea TF-22 ${ }^{\mathrm{T}}$ (Yoon et al., 2004), A. macleodii DSM $6062^{\mathrm{T}}$ and A. marina SW $-47^{\mathrm{T}}$ (Yoon et al., 2003), A. simiduii $\mathrm{AS}^{\mathrm{T}}$ and A. tagae $\mathrm{AT}^{\mathrm{T}}$ (Chiu et al., 2007), A. stellipolaris ANT 69a $\mathrm{a}^{\mathrm{T}}$ (Van Trappen et al., 2004a)]; 5, Glaciecola species [G. agarilytica NO2 ${ }^{\mathrm{T}}$ (Yong et al., 2007), G. chathamensis $\mathrm{S} 18 \mathrm{~K} 6^{\mathrm{T}}$ (Matsuyama et al., 2006), G. mesophila KMM $241^{\mathrm{T}}$ (Romanenko et al., 2003), G. nitratireducens FR1064 ${ }^{\mathrm{T}}$ (Baik et al., 2006), G. pallidula ACAM 615 ${ }^{\mathrm{T}}$ and G. punicea ACAM $611^{\mathrm{T}}$ (Bowman et al., 1998), G. polaris LMG 21857 ${ }^{\mathrm{T}}$ (Van Trappen et al., 2004b), G. psychrophila 170 ${ }^{\mathrm{T}}$ (Zhang et al., 2006)]; 6, Aestuariibacter species [A. halophilus JC2043 ${ }^{\mathrm{T}}$ and A. salexigens $\mathrm{JC}^{2042^{\mathrm{T}}}$ (Yi et al., 2004)]; 7, S. chungwhensis $\mathrm{BH} 030046^{\mathrm{T}}$ (Jeon et al., 2005); 8, B. denitrificans $\mathrm{BD}^{\mathrm{T}}$ (Jean et al., 2006c). -, Not detected/not reported; tr, trace amount detected $(<1 \%)$.

\begin{tabular}{|c|c|c|c|c|c|c|c|c|}
\hline Fatty acid & 1 & 2 & 3 & 4 & 5 & 6 & 7 & 8 \\
\hline $\mathrm{C}_{10: 0} 3-\mathrm{OH}$ & - & - & - & $0-3.3$ & $0-2.8$ & $\operatorname{tr}-4.6$ & $\operatorname{tr}$ & $\operatorname{tr}$ \\
\hline $\mathrm{C}_{11: 0} 3-\mathrm{OH}$ & - & - & - & $0-2.5$ & $0-1.0$ & $\operatorname{tr}-1.0$ & 1.3 & 1.0 \\
\hline $\mathrm{C}_{12: 0} 3-\mathrm{OH}$ & - & - & - & $0-1.9$ & $0-5.5$ & $\operatorname{tr}-1.0$ & 2.5 & 7.1 \\
\hline $\mathrm{C}_{12: 1} 3-\mathrm{OH}$ & - & - & - & $0-\operatorname{tr}$ & $0-6.5$ & $1.1-2.2$ & $\operatorname{tr}$ & - \\
\hline $\mathrm{C}_{14: 0}$ & 1.9 & 1.4 & - & $0-5.7$ & $1.2-7.0$ & $3.1-3.9$ & 3.1 & 2.1 \\
\hline $\mathrm{C}_{15: 0}$ & - & - & - & $0-2.8$ & $\operatorname{tr}-3.0$ & $2.4-3.8$ & 1.8 & - \\
\hline $\mathrm{C}_{15: 1} \omega 8 c$ & - & - & - & $0-2.7$ & $0-3.4$ & $\operatorname{tr}-1.0$ & 1.1 & - \\
\hline $\mathrm{C}_{16: 0}$ & 16.3 & 14.8 & 28.7 & $12.6-23.8$ & $9.4-33.0$ & $15.8-23.9$ & 21.2 & 21.7 \\
\hline iso- $\mathrm{C}_{16: 0}$ & 2.8 & 6.5 & 4.4 & $0-1.1$ & $0-1.5$ & $\operatorname{tr}-1.1$ & $\operatorname{tr}$ & - \\
\hline $\mathrm{C}_{16: 0} \mathrm{~N}$ alcohol & - & - & - & $0-7.4$ & - & - & $\operatorname{tr}$ & 3.7 \\
\hline $\mathrm{C}_{16: 1} \omega 7 c$ alcohol & - & - & - & $0-5.8$ & - & $\operatorname{tr}-2.1$ & - & 2.1 \\
\hline $\mathrm{C}_{17: 1} \omega 8 c$ & - & $\operatorname{tr}$ & - & $0-9.4$ & $2.6-9.5$ & $3.1-6.8$ & 3.6 & 3.8 \\
\hline $\mathrm{C}_{18: 0}$ & - & $\operatorname{tr}$ & - & $0-5.9$ & $0-1.9$ & $\operatorname{tr}-2.9$ & $\operatorname{tr}$ & 1.5 \\
\hline iso- $\mathrm{C}_{18: 0}$ & 1.1 & 6.1 & - & $0-7.8$ & - & - & - & - \\
\hline 10-Methyl $C_{18: 0}$ & - & - & - & - & $0-1.4$ & - & - & - \\
\hline $\mathrm{C}_{18: 1} \omega 6 c$ & - & - & 12.1 & - & - & - & - & - \\
\hline $\mathrm{C}_{18: 1} \omega 7 c$ & 27.1 & 31.4 & 15.3 & $9.9-18.0$ & $0-16.3$ & $11.1-14.0$ & 12.8 & 19.4 \\
\hline $\mathrm{C}_{18: 3} \omega 6 c$ & - & - & - & $0-5.0$ & - & - & - & - \\
\hline Summed feature $2^{\star}$ & 6.9 & 4.5 & - & $0-3.9$ & - & $1.6-2.0$ & 5.3 & - \\
\hline Summed feature $3^{\star}$ & 35.6 & 26.4 & 25.5 & $20.0-33.7$ & $0-60.7$ & $27.2-32.5$ & 31.1 & 24.1 \\
\hline
\end{tabular}

${ }^{\star}$ Summed features represent groups of two fatty acids that cannot be separated by GLC with the MIDI system. Summed feature 2 contains $\mathrm{C}_{14: 0} 3$ $\mathrm{OH}$ and/or iso- $\mathrm{C}_{16: 1}$ I. Summed feature 3 contains $\mathrm{C}_{16: 1} \omega 7 c$ and/or iso- $\mathrm{C}_{15: 0} 2-\mathrm{OH}$.

out from the colonies and release of reducing compounds during agar hydrolysis. Strains $A A M 1^{\mathrm{T}}$ and $\mathrm{AAT}^{\mathrm{T}}$ did not liquefy agar in the plate medium despite their ability to degrade agar. Cells of the strains grown in PY broth appeared to be straight, motile and rod-shaped, with a single polar flagellum, as revealed by TEM (not shown). Strain $\mathrm{AAT}^{\mathrm{T}}$ grew more slowly than $\mathrm{AAM}^{\mathrm{T}}$; strain $\mathrm{AAT1}^{\mathrm{T}}$ was slower to produce colonies on PY plate medium and develop visible turbidity in PY broth. Both strains were facultative anaerobes capable of fermenting cellobiose, dulcitol, D-fructose, D-galactose, D-glucose, Dlactose, maltose, D-mannitol, D-mannose, melibiose, sucrose and D-xylose.

Both strains were susceptible to ampicillin $(10 \mu \mathrm{g})$, carbenicillin $(100 \mu \mathrm{g})$, chloramphenicol $(30 \mu \mathrm{g})$, colistin
$(10 \mu \mathrm{g})$, polymyxin $\mathrm{B}(300 \mathrm{U})$ and tetracycline $(30 \mu \mathrm{g})$, but resistant to clindamycin $(2 \mu \mathrm{g})$, lincomycin $(2 \mu \mathrm{g})$, oxacillin $(1 \mu \mathrm{g})$ and vancomycin $(30 \mu \mathrm{g})$. In addition, strain $\mathrm{AAM1}^{\mathrm{T}}$ was susceptible to erythromycin $(15 \mu \mathrm{g})$, gentamicin $(10 \mu \mathrm{g})$, neomycin $(30 \mu \mathrm{g})$, novobiocin $(30 \mu \mathrm{g})$ and penicillin $\mathrm{G}(10 \mathrm{U})$, intermediately susceptible to kanamycin $(30 \mu \mathrm{g})$, and resistant to cephalothin $(30 \mu \mathrm{g})$, nalidixic acid $(30 \mu \mathrm{g})$ and streptomycin $(10 \mu \mathrm{g})$. On the other hand, strain $\mathrm{AAT} 1^{\mathrm{T}}$ reacted differently to these antibiotics. It was susceptible to cephalothin and nalidixic acid, intermediately susceptible to erythromycin, gentamicin, neomycin, novobiocin and streptomycin, and resistant to kanamycin and penicillin G.

Strains $\mathrm{AAM}^{\mathrm{T}}$ and $\mathrm{AAT}^{\mathrm{T}}$ shared many physiological and morphological characteristics. However, they could be 
Table 2. Characteristics of strains $A A M 1^{\top}$ and $A A T 1^{\top}$ that enable them to be distinguished from members of the genera Agarivorans, Alteromonas, Glaciecola, Aestuariibacter, Salinimonas and Bowmanella

Taxa: 1, strain $\mathrm{AAM1}^{\mathrm{T}}$ (data from this study); 2, strain $\mathrm{AAT1}^{\mathrm{T}}$ (this study), 3, Agarivorans albus $\mathrm{MKT} 106^{\mathrm{T}}$ and other reference strains (Kurahashi \& Yokota, 2004); 4, Alteromonas spp. [A. addita R10SW $13^{\mathrm{T}}$ (Ivanova et al., 2005), A. hispanica F-32 ${ }^{\mathrm{T}}$ (Martínez-Checa et al., 2005), A. litorea TF-22 ${ }^{\mathrm{T}}$ (Yoon et al., 2004), A. macleodii DSM $6062^{\mathrm{T}}$ and A. marina SW-47 ${ }^{\mathrm{T}}$ (Yoon et al., 2003), A. simiduii AS1 ${ }^{\mathrm{T}}$ and A. tagae AT1 ${ }^{\mathrm{T}}$ (Chiu et al., 2007), A.

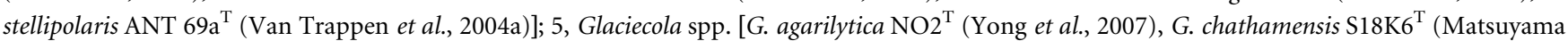
et al., 2006), G. mesophila KMM $241^{\mathrm{T}}$ (Romanenko et al., 2003), G. nitratireducens FR $1064^{\mathrm{T}}$ (Baik et al., 2006), G. pallidula ACAM 615 ${ }^{\mathrm{T}}$ and G. punicea ACAM $611^{\mathrm{T}}$ (Bowman et al., 1998), G. polaris LMG 21857 (Van Trappen et al., 2004b), G. psychrophila 170 ${ }^{\mathrm{T}}$ (Zhang et al., 2006)]; 6, Aestuariibacter species [A. halophilus JC2043 ${ }^{\mathrm{T}}$ and A. salexigens JC2042 ${ }^{\mathrm{T}}$ (Yi et al., 2004)]; 7, S. chungwhensis $\mathrm{BH} 030046^{\mathrm{T}}$ (Jeon et al., 2005); 8, B. denitrificans $\mathrm{BD}^{\mathrm{T}}$ (Jean et al., 2006c). +, Positive; -, negative; $\mathrm{w}$, weakly positive; $\mathrm{v}$, variable among strains; ND, no data available.

\begin{tabular}{|c|c|c|c|c|c|c|c|c|}
\hline Characteristic & 1 & 2 & 3 & 4 & 5 & 6 & 7 & 8 \\
\hline \multicolumn{9}{|l|}{ Fermentation of: } \\
\hline D-Arabinose & $\mathrm{w}$ & - & - & - & - & - & - & - \\
\hline L-Arabinose & + & - & - & - & - & - & - & - \\
\hline Cellobiose & + & + & - & - & - & - & - & - \\
\hline D-Galactose & + & + & - & - & - & - & - & - \\
\hline D-Glucose & + & + & - & - & - & - & - & - \\
\hline Raffinose & $\mathrm{w}$ & - & - & - & - & - & - & - \\
\hline Trehalose & + & - & - & - & - & - & - & - \\
\hline myo-Inositol & $\mathrm{w}$ & - & - & - & - & - & - & - \\
\hline Oxidase & - & - & + & + & + & + & + & + \\
\hline Nitrate reduction & + & + & + & $\mathrm{V}$ & $\mathrm{V}$ & + & - & + \\
\hline Indole production & - & - & ND & - or ND & - or $\mathrm{ND}$ & - & ND & + \\
\hline Poly- $\beta$-hydroxybutyrate accumulation & + & + & ND & $\mathrm{V}$ & - or $\mathrm{ND}$ & - & ND & - \\
\hline \multicolumn{9}{|l|}{ Growth at/in: } \\
\hline $10{ }^{\circ} \mathrm{C}$ & - & - & ND & $\mathrm{V}$ & $\mathrm{V}$ & - & + & + \\
\hline $37^{\circ} \mathrm{C}$ & + & + & + & + & $\mathrm{V}$ & - & + & + \\
\hline $40{ }^{\circ} \mathrm{C}$ & - & - & ND & $\mathrm{V}$ & $\mathrm{V}$ & + & + & + \\
\hline $0 \% \mathrm{NaCl}$ & - & - & - & - & - & - & - & + \\
\hline $1 \% \mathrm{NaCl}$ & + & + & ND & $\mathrm{v}$ & V & + & - & + \\
\hline $3 \% \mathrm{NaCl}$ & + & + & ND & $\mathrm{v}$ & + & + & + & + \\
\hline $10 \% \mathrm{NaCl}$ & - & - & - & $\mathrm{v}$ & V & $\mathrm{V}$ & + & + \\
\hline \multicolumn{9}{|l|}{ Hydrolysis of: } \\
\hline Aesculin & - & - & + & $\mathrm{v}$ & $\mathrm{V}$ & + & + & - \\
\hline Casein & - & - & ND & $\mathrm{V}$ & - or ND & $\mathrm{V}$ & + & + \\
\hline Gelatin & + & $\mathrm{w}$ & - & + & V & + & + & + \\
\hline Urea & - & - & - & - or ND & - or ND & - & + & + \\
\hline Agar & + & + & + & V & V & - & - & - \\
\hline \multicolumn{9}{|l|}{ Utilization of: } \\
\hline D-Fructose & - & - & V & $\mathrm{v}$ & $\mathrm{v}$ & - & - & + \\
\hline D-Galactose & + & $\mathrm{w}$ & ND & $\mathrm{V}$ & $\mathrm{v}$ & $\mathrm{V}$ & ND & + \\
\hline D-Glucose & + & - & + & + & $\mathrm{v}$ & - & + & + \\
\hline L-Lactate & - & - & ND & $\mathrm{V}$ & $\mathrm{V}$ & ND & ND & - \\
\hline D-Lactose & - & - & ND & V & $\mathrm{v}$ & - & - & + \\
\hline Maltose & + & - & + & + or $\mathrm{ND}$ & $\mathrm{v}$ & ND & + & ND \\
\hline D-Mannitol & + & + & + & $\mathrm{V}$ & $\mathrm{v}$ & $\mathrm{ND}$ & - & - \\
\hline D-Mannose & - & - & - & $\mathrm{V}$ & $\mathrm{v}$ & - & ND & - \\
\hline Sucrose & - & - & - & + & $\mathrm{V}$ & $\mathrm{V}$ & ND & + \\
\hline D-Xylose & - & + & - & $\mathrm{V}$ & - or $\mathrm{ND}$ & - & + & + \\
\hline DNA G $+\mathrm{C}$ content $(\mathrm{mol} \%)$ & 52.9 & 52.4 & $48.7-49.7$ & $43.0-46.4$ & $40.0-45.0$ & $48.0-54.0$ & 48.0 & 50.0 \\
\hline
\end{tabular}

differentiated from each other by different reactions in the tests for fermentation of D-arabinose, $\mathrm{L}$-arabinose, melezitose, raffinose, D-ribose, trehalose, myo-inositol and Dsorbitol and utilization of L-arabinose, D-glucose, maltose, raffinose, D-xylose, acetate, fumarate, $\beta$-hydroxybutyrate, malate, pyruvate and tartaric acid as sole carbon and energy sources. Both strains were distinguishable from Agarivorans albus, the eight Alteromonas species studied, the eight Glaciecola species studied, the two Aestuariibacter species studied, S. chungwhensis and B. denitrificans in that they were capable of fermentative metabolism and were negative for the oxidase reaction. Production of agarase 
also distinguished the strains from these species, except for Agarivorans albus (Kurahashi \& Yokota, 2004), Alteromonas addita (Ivanova et al., 2005), Glaciecola agarilytica $\mathrm{NO}^{\mathrm{T}}$ (Yong et al., 2007) and Glaciecola mesophila (Romanenko et al., 2003). Other characteristics useful for differentiating strains $\mathrm{AAM}^{\mathrm{T}}$ and $\mathrm{AAT}^{\mathrm{T}}$ from these closely related species are listed in Table 2.

The data obtained from this polyphasic taxonomic study strongly support the establishment of two different novel species in a novel genus. Therefore, $\mathrm{AAM}^{\mathrm{T}}$ and $\mathrm{AAT}^{\mathrm{T}}$ are proposed as the type strains of Aliagarivorans marinus sp. nov. and Aliagarivorans taiwanensis sp. nov., respectively, of the genus Aliagarivorans gen. nov., with Aliagarivorans marinus as the type species. Characterization data for Aliagarivorans marinus $\mathrm{AAM}^{\mathrm{T}}$ and Aliagarivorans marinus $\mathrm{AAT1}^{\mathrm{T}}$ are given below in the genus and species descriptions.

\section{Description of Aliagarivorans gen. nov.}

Aliagarivorans (A.li.a.ga.ri.vo'rans. L. pronoun alius other, another; N.L. n. Agarivorans a name of a bacterial genus; N.L. masc. n. Aliagarivorans the other Agarivorans).

Members are heterotrophic, Gram-negative rods belonging to the Gammaproteobacteria. Cells grown in broth cultures are motile by means of a single, polar flagellum. Facultative anaerobes capable of both respiratory and fermentative metabolism. Mesophilic, halophilic and agarolytic. Oxidase-negative. Catalase-positive. Major isoprenoid quinone is Q-8. Major cellular fatty acids include $\mathrm{C}_{18: 1} \omega 7 c$, summed feature $3\left(\mathrm{C}_{16: 1} \omega 7 c\right.$ and/or iso- $\left.\mathrm{C}_{15: 0} 2-\mathrm{OH}\right)$ and $\mathrm{C}_{16: 0}$. The DNA $\mathrm{G}+\mathrm{C}$ content is approximately 52 $53 \mathrm{~mol} \%$. The type species is Aliagarivorans marinus.

\section{Description of Aliagarivorans marinus sp. nov.}

Aliagarivorans marinus (ma.ri'nus. L. masc. adj. marinus of the sea, marine).

Has the following characteristics in addition to those given for the genus. Cells during late exponential to early stationary phase of growth in broth cultures are straight rods, approximately $1.4-2.0 \mu \mathrm{m}$ long and $1.0-1.2 \mu \mathrm{m}$ wide. Colonies produced on marine agar and PY plate medium at $30{ }^{\circ} \mathrm{C}$ for $4-7$ days are circular (approx. $1-2 \mathrm{~mm}$ in diameter), off-white, opaque, convex, non-luminescent and agarolytic; agarolytic activity is indicated by the development of softening and depressions, but not by liquefaction of the agar surrounding the colonies. Swarming does not occur. Able to ferment D-glucose, Darabinose (weakly), L-arabinose, cellobiose, D-fructose (weakly), D-galactose, D-lactose, maltose, D-mannose, melibiose, melezitose, raffinose (weakly), sucrose (weakly), trehalose, D-xylose, dulcitol, myo-inositol (weakly fermentative), D-mannitol and D-sorbitol (weakly) with production of acid, but no gas. Unable to ferment D-ribose. Nitrate is reduced to nitrite, but not further to $\mathrm{N}_{2} \mathrm{O}$ or $\mathrm{N}_{2}$. Poly- $\beta$-hydroxybutyrate is accumulated as an intracellular reserve product. Indole is not produced from tryptophan Growth occurs between 15 and $37{ }^{\circ} \mathrm{C}$, with optimum growth at $25-30{ }^{\circ} \mathrm{C}$; no growth occurs at $4-10$ or $40-42{ }^{\circ} \mathrm{C}$. Sodium ions are required for growth; growth occurs at $\mathrm{NaCl}$ levels of $1-7 \%(\mathrm{w} / \mathrm{v})$, with optimum growth at 2$3 \%$, and no growth occurs at 0 or $8-10 \% \mathrm{NaCl}$. Able to grow over the $\mathrm{pH}$ range 7-9, but not at $\mathrm{pH} 5-6$. Not haemolytic. Agar, alginate and gelatin are hydrolysed, but aesculin, casein, cellulose, chitin, DNA, lecithin, starch, Tween 80 and urea are not. Arginine dihydrolase, lysine decarboxylase and ornithine decarboxylase are absent. The following constitutive enzyme activities are detected in API ZYM tests: leucine arylamidase, esterase (C4), $\beta$-galactosidase and naphthol-AS-BI-phosphohydrolase. Able to grow on the following compounds as sole carbon and energy sources: L-arabinose, cellobiose, D-galactose, D-glucose, maltose, D-mannitol, acetate, fumarate, $\beta$-hydroxybutyrate, pyruvate, $\mathrm{L}$-alanine, $\mathrm{L}$-aspartate, $\mathrm{L}$-glutamate and L-glutamine. Unable to grow on the following compounds as sole carbon and energy sources: D-arabinose, D-fructose, Dlactose, D-mannose, melibiose, raffinose, L-rhamnose, Dribose, sucrose, D-xylose, trehalose, salicin, dulcitol, glycerol, myo-inositol, D-sorbitol, citrate, lactate, malate, succinate, tartaric acid, L-arginine, L-citrulline, L-glycine, Lhistidine, L-isoleucine, L-leucine, L-lysine, L-ornithine, L-phenylalanine, L-serine, L-threonine, L-tyrosine, L-tryptophan and L-valine.

The type strain is $\mathrm{AAM}^{\mathrm{T}}\left(=\mathrm{BCRC} 17888^{\mathrm{T}}=\mathrm{JCM} 15522^{\mathrm{T}}\right)$, isolated from shallow coastal water from An-Ping Harbour, Tainan, Taiwan. The DNA G + C content of the type strain is $52.9 \mathrm{~mol} \%$.

\section{Description of Aliagarivorans taiwanensis sp. nov.}

Aliagarivorans taiwanensis (tai.wan.en'sis. N.L. masc. adj. taiwanensis pertaining to Taiwan, where the type strain was isolated).

Has the following characteristics in addition to those given for the genus. Cells during late exponential to early stationary phase of growth in broth cultures are straight rods, approximately $1.2-2.7 \mu \mathrm{m}$ long and $0.5-1.2 \mu \mathrm{m}$ wide. Colonies produced on marine agar and PY plate medium at $30{ }^{\circ} \mathrm{C}$ for $4-7$ days are circular (approx. $1-2 \mathrm{~mm}$ in diameter), off-white, opaque, convex, non-luminescent and agarolytic; agarolytic activity is indicated by the development of softening and depressions, but not by liquefaction of the agar surrounding the colonies. Swarming does not occur. Nitrate is reduced to nitrite, but not further to $\mathrm{N}_{2} \mathrm{O}$ or $\mathrm{N}_{2}$. Poly- $\beta$-hydroxybutyrate is accumulated as an intracellular reserve product. Indole is not produced from tryptophan. Growth occurs between 15 and $37^{\circ} \mathrm{C}$, with optimum growth at $25-30{ }^{\circ} \mathrm{C}$; no growth occurs at $4-10$ or $40-42{ }^{\circ} \mathrm{C}$. Sodium ions are required for growth; growth occurs at $\mathrm{NaCl}$ levels of $1-7 \%(\mathrm{w} / \mathrm{v})$, with optimum growth at $2-3 \%$, and no growth occurs at 0 or $8-$ $10 \% \mathrm{NaCl}$. Able to grow over the $\mathrm{pH}$ range $7-9$, but not at 
pH 5-6. Not haemolytic. Agar, alginate and gelatin (weakly) are hydrolysed, but aesculin, casein, cellulose, chitin, DNA, lecithin, starch, Tween 80 and urea are not. Able to ferment D-galactose (weakly), D-glucose, cellobiose, D-fructose, D-lactose (weakly), maltose, D-mannose, melibiose, sucrose, D-xylose (weakly), dulcitol (weakly) and Dmannitol with production of acid, but no gas. Unable to ferment D-arabinose, L-arabinose, melezitose, raffinose, Dribose, trehalose, myo-inositol or D-sorbitol. Able to grow on the following compounds as sole carbon and energy sources: cellobiose, raffinose, D-xylose, D-mannitol, Laspartate, L-glutamate, malate, tartaric acid, L-glutamine and L-ornithine. Unable to grow on the following compounds as sole carbon and energy sources: Darabinose, L-arabinose, D-fructose, D-galactose, D-glucose, D-lactose, maltose, D-mannose, melibiose, L-rhamnose, Dribose, sucrose, trehalose, salicin, dulcitol, glycerol, myoinositol, D-sorbitol, citrate, acetate, fumarate, $\beta$-hydroxybutyrate, lactate, succinate, pyruvate, L-alanine, L-arginine, L-citrulline, L-glycine, L-histidine, L-isoleucine, L-leucine, L-lysine, L-phenylalanine, L-serine, L-threonine, L-tyrosine, L-tryptophan and L-valine. Arginine dihydrolase, lysine decarboxylase and ornithine decarboxylase are absent. Activities of acid phosphatase, alkaline phosphatase, esterase (C4), esterase lipase (C8) (weak reaction), $\alpha$ galactosidase, $\beta$-galactosidase, $\beta$-glucosidase, leucine arylamidase, naphthol-AS-BI-phosphohydrolase and valine arylamidase (weak reaction) are present in API ZYM tests.

The type strain is $\operatorname{AAT1}^{\mathrm{T}}\left(=\mathrm{BCRC} 17889^{\mathrm{T}}=\mathrm{JCM} 15537^{\mathrm{T}}\right)$, isolated from shallow coastal water from An-Ping Harbour, Tainan, Taiwan. The DNA G $+\mathrm{C}$ content of the type strain is $52.4 \mathrm{~mol} \%$.

\section{Acknowledgements}

This study was supported by grants NSC95-2221-E-426-015, NSC952221-E-426-005-MY2, NSC95-2621-B-002-010 and NSC96-2621-B002-009-MY2 from the National Science Council, Taiwan.

\section{References}

Baik, K. S., Park, Y.-D., Seong, C. N., Kim, E. M., Bae, K. S. \& Chun, J. (2006). Glaciecola nitratireducens sp. nov., isolated from seawater. Int J Syst Evol Microbiol 56, 2185-2188.

Bowman, J. P. \& McMeekin, T. A. (2005). Genus I. Alteromonas Baumann, Baumann, Mandel and Allen 1972, 418, emend. Gauthier, Gauthier and Christen 1995a, 760. In Bergey's Manual of Systematic Bacteriology, 2nd edn, vol. 2, part B, pp. 444-447. Edited by D. J. Brenner, N. R. Krieg, J. T. Staley \& G. M. Garrity. New York: Springer.

Bowman, J. P., McCammon, S. A., Brown, J. L. \& McMeekin, T. A. (1998). Glaciecola punicea gen. nov., sp. nov. and Glaciecola pallidula gen. nov., sp. nov.: psychrophilic bacteria from Antarctic sea-ice habitats. Int J Syst Bacteriol 48, 1213-1222.

Chiu, H.-H., Shieh, W. Y., Lin, S. Y., Tseng, C.-M., Chiang, P.-W. \& Wagner-Döbler, I. (2007). Alteromonas tagae sp. nov. and Alteromonas simiduii sp. nov., mercury-resistant bacteria isolated from a Taiwanese estuary. Int J Syst Evol Microbiol 57, 1209-1216.
Ivanova, E. P., Bowman, J. P., Lysenko, A. M., Zhukova, N. V., Gorshkova, N. M., Sergeev, A. F. \& Mikhailov, V. V. (2005). Alteromonas addita sp. nov. Int J Syst Evol Microbiol 55, 1065-1068.

Jean, W. D., Shieh, W. Y. \& Liu, T. Y. (2006a). Thalassomonas agarivorans sp. nov., a marine agarolytic bacterium isolated from shallow coastal water of An-Ping Harbour, Taiwan, and emended description of the genus Thalassomonas. Int J Syst Evol Microbiol 56, 1245-1250.

Jean, W. D., Shieh, W. Y. \& Chiu, H.-H. (2006b). Pseudidiomarina taiwanensis gen. nov., sp. nov., a marine bacterium isolated from shallow coastal water of An-Ping Harbour, Taiwan, and emended description of the family Idiomarinaceae. Int J Syst Evol Microbiol 56, 899-905.

Jean, W. D., Chen, J.-S., Lin, Y.-T. \& Shieh, W. Y. (2006c). Bowmanella denitrificans gen. nov., sp. nov., a denitrifying bacterium isolated from seawater from An-Ping Harbour, Taiwan. Int J Syst Evol Microbiol 56, 2463-2467.

Jean, W. D., Leu, T.-Y., Lee, C.-Y., Chu, T.-J., Lin, S. Y. \& Shieh, W. Y. (2009). Pseudidiomarina marina sp. nov. and Pseudidiomarina tainanensis sp. nov. and reclassification of Idiomarina homiensis and Idiomarina salinarum as Pseudidiomarina homiensis comb. nov. and Pseudidiomarina salinarum comb. nov., respectively. Int J Syst Evol Microbiol 59, 53-59.

Jeon, C. O., Lim, J.-M., Park, D.-J. \& Kim, C.-J. (2005). Salinimonas chungwhensis gen. nov., sp. nov., a moderately halophilic bacterium from a solar saltern in Korea. Int J Syst Evol Microbiol 55, 239-243.

Kurahashi, M. \& Yokota, A. (2004). Agarivorans albus gen. nov., sp. nov., a $\gamma$-proteobacterium isolated from marine animals. Int $J$ Syst Evol Microbiol 54, 693-697.

Martínez-Checa, F., Béjar, V., Llamas, I., del Moral, A. \& Quesada, E. (2005). Alteromonas hispanica sp. nov., a polyunsaturated-fatty-acidproducing, halophilic bacterium isolated from Fuente de Piedra, southern Spain. Int J Syst Evol Microbiol 55, 2385-2390.

Matsuyama, H., Hirabayashi, T., Kasahara, H., Minami, H., Hoshino, T. \& Yumoto, I. (2006). Glaciecola chathamensis sp. nov., a novel marine polysaccharide-producing bacterium. Int J Syst Evol Microbiol 56, 2883-2886.

Romanenko, L. A., Zhukova, N. V., Rohde, M., Lysenko, A. M., Mikhailov, V. V. \& Stackebrandt, E. (2003). Glaciecola mesophila sp. nov., a novel marine agar-digesting bacterium. Int $J$ Syst Evol Microbiol 53, 647-651.

Scheuermayer, M., Gulder, T. A. M., Bringmann, G. \& Hentschel, U. (2006). Rubritalea marina gen. nov., sp. nov., a marine representative of the phylum 'Verrucomicrobia', isolated from a sponge (Porifera). Int J Syst Evol Microbiol 56, 2119-2124.

Shieh, W. Y. \& Jean, W. D. (1998). Alterococcus agarolyticus gen. nov., sp. nov., a halophilic thermophilic bacterium capable of agar degradation. Can J Microbiol 44, 637-645.

Shieh, W. Y., Chen, A.-L. \& Chiu, H.-H. (2000). Vibrio aerogenes sp. nov., a facultatively anaerobic marine bacterium that ferments glucose with gas production. Int J Syst Evol Microbiol 50, 321-329.

Shieh, W. Y., Lin, Y.-T. \& Jean, W. D. (2004). Pseudovibrio denitrificans gen. nov., sp. nov., a marine, facultatively anaerobic, fermentative bacterium capable of denitrification. Int J Syst Evol Microbiol 54, 2307-2312.

Shieh, W. Y., Liu, T. Y., Lin, S. Y., Jean, W. D. \& Chen, J.-S. (2008). Simiduia agarivorans gen. nov., sp. nov., a marine, agarolytic bacterium isolated from shallow coastal water from Keelung, Taiwan. Int J Syst Evol Microbiol 58, 895-900.

Van Trappen, S., Tan, T.-L., Yang, J., Mergaert, J. \& Swings, J. (2004a). Alteromonas stellipolaris sp. nov., a novel, budding, prosthecate bacterium from Antarctic seas, and emended description of the genus Alteromonas. Int J Syst Evol Microbiol 54, 1157-1163.

Van Trappen, S., Tan, T.-L., Yang, J., Mergaert, J. \& Swings, J. (2004b). Glaciecola polaris sp. nov., a novel budding and prosthecate 
bacterium from the Arctic Ocean, and emended description of the genus Glaciecola. Int J Syst Evol Microbiol 54, 1765-1771.

Yi, H., Bae, K. S. \& Chun, J. (2004). Aestuariibacter salexigens gen. nov., sp. nov. and Aestuariibacter halophilus sp. nov., isolated from tidal flat sediment, and emended description of Alteromonas macleodii. Int J Syst Evol Microbiol 54, 571-576.

Yong, J.-J., Park, S.-J., Kim, H.-J. \& Rhee, S.-K. (2007). Glaciecola agarilytica sp. nov., an agar-digesting marine bacterium from the East Sea, Korea. Int J Syst Evol Microbiol 57, 951-953.

Yoon, J.-H., Kim, I.-G., Kang, K. H., Oh, T.-K. \& Park, Y.-H. (2003). Alteromonas marina sp. nov., isolated from sea water of the East Sea in Korea. Int J Syst Evol Microbiol 53, 1625-1630.
Yoon, J.-H., Yeo, S.-H., Oh, T.-K. \& Park, Y.-H. (2004). Alteromonas litorea sp. nov., a slightly halophilic bacterium isolated from an intertidal sediment of the Yellow Sea in Korea. Int J Syst Evol Microbiol 54, 1197-1201.

Yoon, J., Ishikawa, S., Kasai, H. \& Yokota, A. (2007). Persicitalea jodogahamensis gen. nov., sp. nov., a marine bacterium of the family 'Flexibacteraceae', isolated from seawater in Japan. Int J Syst Evol Microbiol 57, 1014-1017.

Zhang, D.-C., Yu, Y., Chen, B., Wang, H.-X., Liu, H.-C., Dong, X.-Z. \& Zhou, P.-J. (2006). Glaciecola psychrophila sp. nov., a novel psychrophilic bacterium isolated from the Arctic. Int $J$ Syst Evol Microbiol 56, 2867-2869. 